\title{
Pengembangan Kawasan Wisata Bahari Kecamatan Watulimo, Kabupaten Trenggalek
}

\author{
Siti Fadilah dan Rimadewi Suprihardjo \\ Jurusan Perencanaan Wilayah dan Kota, Fakultas Teknik Sipil dan Perencanaan \\ Institut Teknologi Sepuluh Nopember (ITS) \\ Jl. Arief Rahman Hakim, Surabaya 60111 Indonesia \\ e-mail: rimadewi54@yahoo.com
}

\begin{abstract}
Abstrak - Kecamatan Watulimo, Kabupaten Trenggalek merupakan salah satu wilayah di Provinsi Jawa Timur yang memiliki potensi wisata bahari yang cukup besar, akan tetapi keberadaan daya tarik tersebut belum terkelola dengan baik. Permasalahan yang ada adalah potensi-potensi yang terdapat di Kecamatan Watulimo belum terintegrasi dan tereksplorasi, sehingga dibutuhkan suatu arahan pengembangan kawasan. Sebelum menentukan arahan pengembangan dilakukan analisis karakteristik objek daya tarik wisata (ODTW) bahari terlebih dahulu menggunakan analisis deskriptif kualitatif. Tahap selanjutnya yaitu menganalisis faktor-faktor yang mempengaruhi pengembangan kawasan wisata menggunakan analisis deksriptif dan analisis Delphi. Analisis Delphi ini untuk mendapatkan konsensus dari para responden yang berpengaruh terhadap faktor yang terbentuk. Maka tahap terakhir yang dilakukan adalah analisis perumusan arahan pengembangan kawasan menggunakan analisis triangulasi. Sehingga hasil yang didapatkan yaitu terbentuklah arahan pengembangan kawasan wisata bahari Kecamatan Watulimo yang terdiri dari 4 ODTW. Hasil akhir penelitian ini menghasilkan 10 arahan pengembangan kawasan wisata bahari Kecamatan Watulimo yang kemudian arahan tersebut diharapkan dapat mengembangkan potensi wisata bahari Watulimo.
\end{abstract}

Kata Kunci-Wisata Bahari, Pengembangan Kawasan Wisata, Kecamatan Watulimo

\section{PENDAHULUAN}

$\mathrm{W}$ ISATA bahari merupakan merupakan salah satu jenis pariwisata yang memiliki sumbangan besar terhadap perekonomian. Kontribusi pariwisata bahari terhadap pembangunan nasional berupa penyediaan lapangan pekerjaan dan aktivitas ekonomi lainnya (multiplier effect) serta pemasukan devisa bagi Negara [1]. Kabupaten Trenggalek merupakan salah satu kabupaten di Jawa Timur yang memiliki kegiatan wisata dengan jumlah banyak dan jenis kegiatan wisata yang beragam. Kabupaten Trenggalek mempunyai panjang pantai sekitar $96 \mathrm{~km}$ dengan luas laut \pm 71.117 ha serta jumlah pulau sebanyak 57 pulau [2].

Kecamatan Watulimo, Kabupaten Trenggalek merupakan salah satu wilayah di Provinsi Jawa Timur yang memiliki potensi bahari yang berlimpah [3]. Di kawasan ini terdapat sejumlah objek wisata alam yang menarik, diantaranya Pantai Prigi dengan garis pantai yang membentang sejauh $2,5 \mathrm{~km}$, Pantai Karanggongso dengan pasir putihnya dan air yang jernih, Pantai Damas dengan pantai yang masih alami, serta Pantai Cengkrong yang memiliki wisata mangrove [2]. Hal ini menunjukkan bahwa Kecamatan Watulimo memiliki potensi wisata bahari yang cukup besar.

Akan tetapi, pengembangan wisata Watulimo saat ini masih belum optimal. Kegiatan di masing-masing objek dan daya tarik wisata masih berjalan sendiri-sendiri. Hal ini dapat dilihat dari kunjungan wisatawan yang hanya terfokus pada satu objek wisata yaitu Pantai Karanggongso, sedangkan untuk objek wisata lain masih rendah bahkan mengalami penurunan setiap tahunnya [4]. Belum berkembangnya wisata yang ada mengakibatkan belum terwujudnya lingkage antar obyek wisata di Kecamatan Watulimo, sehingga antar obyek wisata yang satu dengan obyek wisata yang lain tidak dapat memberi kontribusi sesuai dengan peruntukannya masingmasing. Untuk mengoptimalkan potensi yang ada diperlukan suatu arahan sebagai upaya untuk mengembangkan sektor pariwisata di Kecamatan Watulimo dengan memadukan dan mengintegrasikan sejumlah potensi wisata bahari yang ada dalam satu kawasan untuk meningkatkan kunjungan wisatawan.

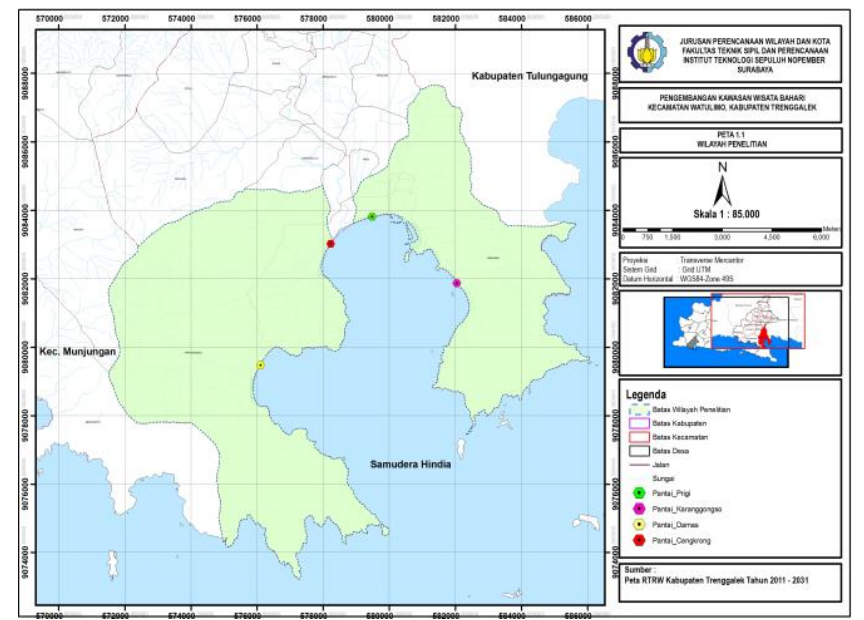

Gambar. 1. Peta Orientasi Wilayah Penelitian Kawasan Wisata Bahari Kecamatan Watulimo 


\section{METODE PENELITIAN}

Jenis penelitian ini adalah jenis penelitian kualitatif. Pendekatan yang dilakukan pada penelitian ini adalah pendekatan rasionalisme. Penelitian ini bertujuan untuk merumuskan arahan pengembangan kawasan wisata bahari Kecamatan Watulimo Kabupaten Trenggalek.

Metode analisa yang digunakan dalam penelitian ini antara lain analisis deskriptif kualitaif untuk mengidentifikasi karakteristik objek dan daya tarik wisata bahari di Kecamatan Watulimo. Faktor-faktor yang mempengaruhi pengembangan kawasan wisata bahari Kecamatan Watulimo menggunakan metode analisis deskriptif dan analisis Delphi. Kemudian tahap akhir adalah perumusan arahan pengembangan kawasan wisata bahari Kecamatan Watulimo menggunakan pendekatan triangulasi.

\section{HASIL DAN DISKUSI}

\section{A. Analisis Karakteristik ODTW Bahari di Kawasan Wisata} Kecamatan Watulimo

Dari hasil penelitian, terdapat 4 ODTW yang berpotensi di Kecamatan Watulimo dan memiliki karakteristik berbeda, yaitu Pantai Prigi, Pantai Karanggongso/Pasir Putih, Pantai Cengkrong dan Pantai Damas. Potensi yang ada di Kawasan Watulimo dikelompokkan sebagai wisata pantai atau bahari.

\section{Tabel 1. Karakteristik ODTW Bahari Kecamatan Watulimo}

\begin{tabular}{|c|c|c|}
\hline No. & $\begin{array}{c}\text { Jenis Objek } \\
\text { Wisata }\end{array}$ & Karakteristik \\
\hline 1. & Pantai Prigi & $\begin{array}{l}\text { Panjang pantai } 2,5 \mathrm{~km} \text { dengan pasir } \\
\text { berwarna kecoklatan, terdapat } \\
\text { keindahan panorama laut lepas dan } \\
\text { pulau-pulau kecil, ombaknya tidak } \\
\text { terlalu besar. Atraksi/ kegiatan } \\
\text { wisata bahari berupa point of view } \\
\text { dan berenang. }\end{array}$ \\
\hline 2. & $\begin{array}{l}\text { Pantai } \\
\text { Karanggongso }\end{array}$ & $\begin{array}{l}\text { Ombak relative tenang, terdapat } \\
\text { hamparan pasir putih sejauh } 1,5 \mathrm{~km} \text {. } \\
\text { Atraksi bahari berupa berenang, } \\
\text { berperahu, banana boat, dan point } \\
\text { of view. }\end{array}$ \\
\hline 3. & Pantai Damas & $\begin{array}{l}\text { Keindahan alam pantai yang masih } \\
\text { relative alami, terdapat pohon } \\
\text { kelapa di tepi pantai, pasir berwarna } \\
\text { kombak tidak terlalu besar, serta } \\
\text { terdapat kenekaragaman ikan dan } \\
\text { udang karang. Karakter kegiatan } \\
\text { wisata yang ada saat ini hanya } \\
\text { berupa point of view (panorama } \\
\text { keindahan alam), berjemur. Objek } \\
\text { Daya Tarik Wisata Pantai Damas } \\
\text { memiliki potensi bahari yang } \\
\text { berkaitan dengan olahraga air } \\
\text { berupa surfing, volli pantai, dan } \\
\text { berperahu. }\end{array}$ \\
\hline 4. & Pantai Cengkrong & $\begin{array}{l}\text { Objek dengan karakteristik bahari } \\
\text { berupa pantai yang masih alami } \\
\text { dengan hamparan pasir berwarna } \\
\text { kecoklatan serta terdapat banyak }\end{array}$ \\
\hline
\end{tabular}

\begin{tabular}{c|c|l}
\hline No. & $\begin{array}{c}\text { Jenis Objek } \\
\text { Wisata }\end{array}$ & \multicolumn{1}{c}{ Karakteristik } \\
\hline & & $\begin{array}{l}\text { kerang yang bertebaran. Selain itu, } \\
\text { terdapat ekowisata mangrove yang } \\
\text { menjadi salah satu daya tarik di } \\
\text { kawasan ini. Tidak ada atraksi } \\
\text { wisata bahari. }\end{array}$ \\
\hline \hline
\end{tabular}

Sumber : Hasil Analisis, 2015.

Karakteristik ODTW (objek dan daya tarik wisata) bahari Kecamatan Watulimo dapat dilihat pada gambar 2.

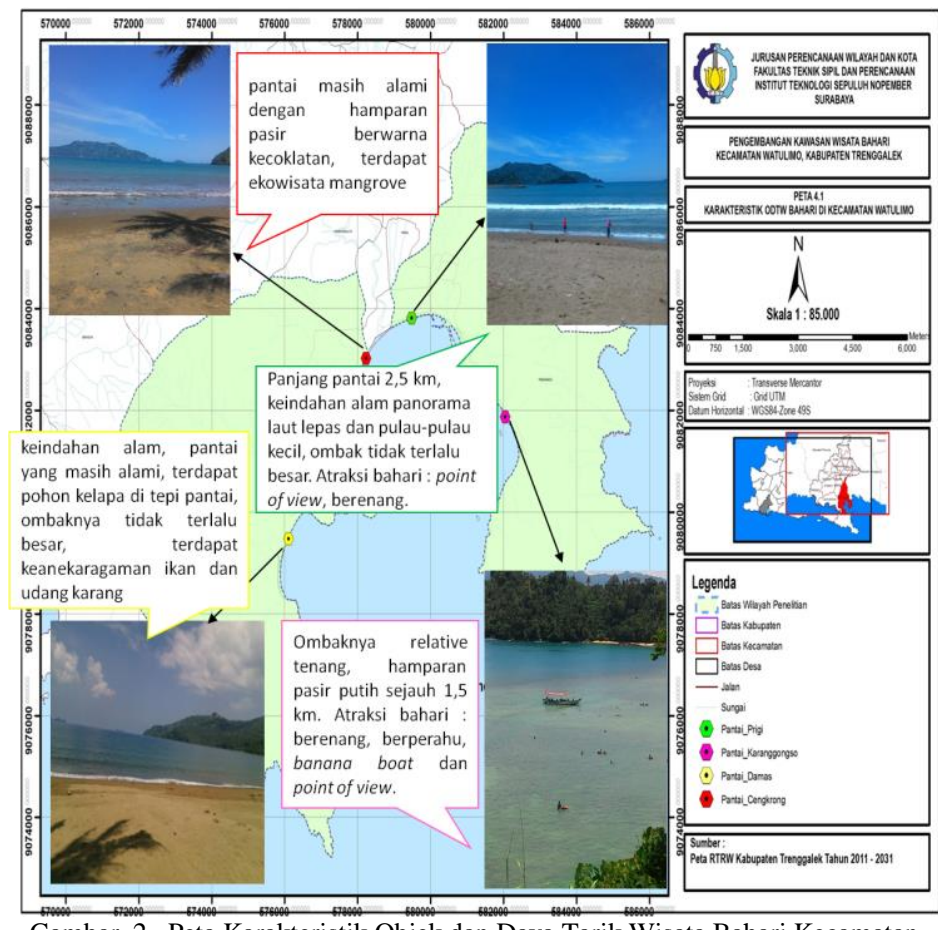

Gambar. 2. Peta Karakteristik Objek dan Daya Tarik Wisata Bahari Kecamatan Watulimo

\section{B. Analisis Faktor-faktor yang Mempengaruhi} Pengembangan Kawasan Wisata Bahari Kecamatan Watulimo

Adapun dari penelitian ini menemukan faktor-faktor yang mempengaruhi pengembangan kawasan wisata bahari. Faktorfaktor yang didapat berasal dari variabel wisata bahari, komponen pariwisata dan pariwisata terpadu kemudian dianalisa deskriptif dengan menganalisis kondisi eksisting serta studi literatur.

Dari proses analisa mendapatkan beberapa faktor yang mempengaruhi pengembangan kawasan wisata bahari Kecamatan Watulimo, yaitu, (a) Meningkatkan atraksi wisata bahari di setiap objek wisata yang belum berkembang, (b) Mengadakan jalur wisata yang melalui serangkaian objekobjek wisata bahari Watulimo, (c) Mengadakan moda transportasi wisata yang menghubungkan antar objek wisata, (d) Meningkatkan kualitas sarana/prasarana pendukung wisata, (e) Meningkatkan peran serta masyarakat terhadap kegiatan wisata bahari Watulimo, (f) Mengembangkan SDM yang terdapat di kawasan wisata bahari Watulimo, (g) Mengadakan kerjasama antar stakeholder terkait dalam pengembangan wisata bahari Watulimo. 


\section{Analisis Perumusan Arahan Pengembangan Kawasan Wisata Bahari Kecamatan Watulimo, Kabupaten Trenggalek}

Dalam merumuskan arahan pengembangan kawasan wisata bahari Watulimo dilakukan dengan menggunakan analisis triangulasi. Dimana yang menjadi pedoman utama dalam perumusan arahan adalah hasil dari sasaran sebelumnya yaitu ke-7 faktor yang mempengaruhi pengembangan kawasan wisata bahari Watulimo, yang disesuaikan dengan karakteristik kondisi eksisting serta kebijakan yang berkaitan dengan pengembangan wisata bahari.

Arahan pengembangan kawasan wisata bahari Watulimo yang dihasilkan dalam penelitian adalah sebagai berikut:

a. Peningkatan daya tarik wisata melalui penambahan atraksi wisata di setiap objek yang kurang berkembang.

- Pantai Prigi : Meningkatkan daya tarik wisata melalui penambahan atraksi wisata bahari berupa berperahu dan olahraga pantai (voli pantai); serta tetap melestarikan upacara petik laut sebagai daya tarik wisata.

- Pantai Damas : Menambah sajian atraksi wisata berupa surfing, berperahu, dan olahraga volli pantai.

b. Integrasi antar atraksi wisata bahari yaitu banana boat dan berperahu di Pantai Karanggongso dilanjutkan dengan point of view, olahraga air, berbelanja ikan segar serta upacara tradisional di Pantai Prigi, selanjutnya wisatawan dapat menikmati wisata mangrove di Pantai Cengkrong, serta atraksi wisata surfing dan memancing di Pantai Damas. Dengan adanya integrasi antar objek wisata bahari ini dapat memberikan kesan tersendiri bagi wisatawan dan dapat menarik banyak wisatawan sehingga wisatawan setelah mengunjungi obyek wisata mendapatkan suatu pengalaman perjalanan yang menarik (travel experience).

c. Penambahan luas kawasan pada objek wisata pantai Karanggongso, yaitu pengembangannya ke arah timur.

d. Membangun jalur wisata dengan menyediakan sarana transportasi umum untuk menuju serangkaian objek-objek wisata bahari yang terdapat di kawasan. Pembentukan jalur wisata terdiri dari jalur wisata internal kawasan yaitu melalui serangkaian objek wisata bahari banana boat dan berperahu di pantai Karanggongso - point of view, olahraga air, berbelanja ikan segar serta upacara tradisional di Pantai Prigi - wisata mangrove di Pantai Cengkrong - wisata bahari surfing dan memancing di Pantai Damas. Untuk jalur wisata darat sesuai dengan jaringan jalan yang sudah ada, sedangkan untuk jalur laut disesuaikan dengan alur pelayaran

e. Pengadaan moda angkutan khusus wisata yang menghubungkan antar objek wisata bahari (baik darat maupun laut) berupa mobil atau mini bus, serta perahu khusus wisata.

f. Peningkatan kualitas dan penambahan sarana akomodasi/penginapan di setiap objek wisata bahari yang terdapat di kawasan wisata Watulimo.

g. Peningkatan layanan fasilitas parkir berupa perluasan area parkir yang memenuhi kebutuhan pengunjung pada objek wisata yang memiliki luas area yang lebih. h. Peningkatan kualitas prasarana listrik dan air bersih pada objek wisata yang belum terlayani dengan optimal.

i. Mengadakan kerjasama antar pemerintah, swasta dan masyarakat dalam hal pengelolaan, perencanaan pengembangan kawasan wisata bahari Watulimo.

j. Peningkatan Sumber Daya Manusia dan pemberdayaan kualitas Kelompok Sadar Wisata (Pokdarwis) di Desa Tasikmadu dan Kelompok Pengawas Wisata (Pokmawas) di Desa Karanggandu dengan penguasaan ilmu dan teknologi, ketrampilan dan kewirausahaan.

Arahan pengembangan kawasan wisata bahari Kecamatan Watulimo dapat dilihat pada Gambar 3.

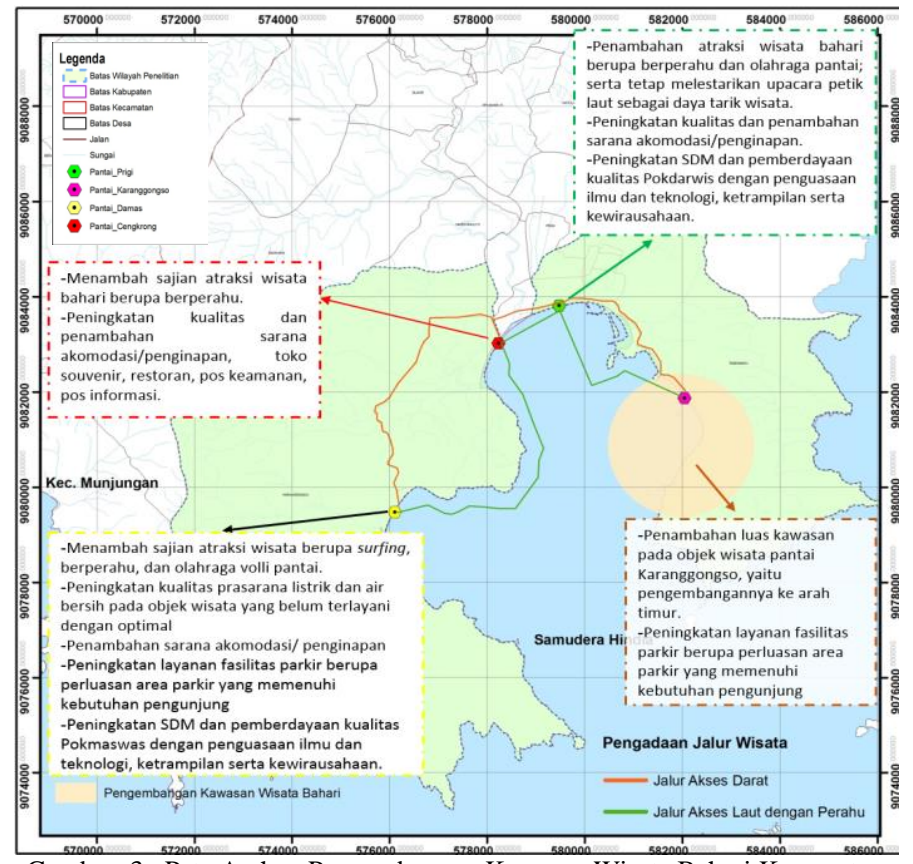

Gambar. 3. Peta Arahan Pengembangan Kawasan Wisata Bahari Kecamatan Watulimo

\section{KESIMPULAN}

Pengembangan kawasan wisata bahari Watulimo diarahkan pada peningkatan daya tarik wisata melalui penambahan atraksi wisata bahari, penambahan luas kawasan, dan integrasi antar atraksi wisata bahari di Kecamatan Watulimo. Pengembangan kawasan juga didukung oleh aksesibilitas, berupa pengadaan jalur wisata internal melalui serangkaian objek wisata bahari melewati akses darat yang disesuaikan dengan jaringan jalan, serta penyediaan moda transportasi khusus wisata berupa mobil atau mini bus, serta perahu khusus wisata. Peningkatan kualitas dan penambahan sarana akomodasi/penginapan di setiap objek wisata bahari yang terdapat di kawasan wisata Watulimo. Melalui arahan pengembangan kawasan wisata bahar Kecamatan Watulimo ini diharapkan dapat menjadi masukan penting bagi pemerintah Kabupaten Trenggalek dan stakeholder lainnya dalam mengembangkan potensi kawasan wisata di Kabupaten Trenggalek. 


\section{UCAPAN TERIMA KASIH}

Puji syukur penulis panjatkan kepada Allah SWT atas berkah, karunia dan tuntunan-Nya sehingga laporan Tugas Akhir dengan judul "Pengembangan Kawasan Wisata Bahari Kecamatan Watulimo Kabupaten Trenggalek" ini dapat terselesaikan.

Penulis mengucapkan terima kasih kepada Direktorat Pendidikan Tinggi, Departemen Pendidikan dan Kebudayaan Republik Indonesia yang telah memberikan dukungan finansial melalui Beasiswa Bidik Misi tahun 2011-2015. Penulis juga mengucapkan banyak terima kasih kepada dosen pembimbing dan dosen penguji yang telah memberikan banyak saran dan masukan dalam penelitian ini.

\section{DAFTAR PUSTAKA}

[1] Dahuri et al., (2001). Pengelolaan Sumberdaya Wilayah Pesisir dan Lautan Secara Terpadu. Bogor: Pradnya Paramita.

[2] Rencana Induk Pengembangan Pariwisata Kabupaten Trenggalek Tahun Anggaran 2007.

[3] Humas Trenggalek. 2012. Peringatan Hari Nusantara XIII Provinsi Jawa Timur di Pelabuhan Perikanan Nusantara (PPN). Diunduh pada 12 Oktober 2014 dari http://humastrenggalek.blogspot.com/2012/12/peringatan-hari-nusantara-xiiiprovinsi.html.

[4] Dinas Pariwisata, Pemuda dan Olahraga Kabupaten Trenggalek, 2014. Data Jumlah Kunjungan Wisatawan. Dinas Pariwisata, Pemuda dan Olahraga Kabupaten Trenggalek

[5] Diktat Metodologi Penelitian (2013). Jurusan Perencanaan Wilayah dan Kota ITS.

[6] Putra, Agung; dkk. 2006. Thesis. Efisiensi Tata Letak Fasilitas dan Sarana Proyek Dalam Mendukung Metode Pekerjaan Konstruksi (Studi Kasus Proyek Jakarta City Centre, Sudirman Park, Sudirman Place). Semarang: Universitas Diponegoro. 